\title{
Assessing the Viability of Vacant Farmhouse Market in China: A Case Study in Sichuan
}

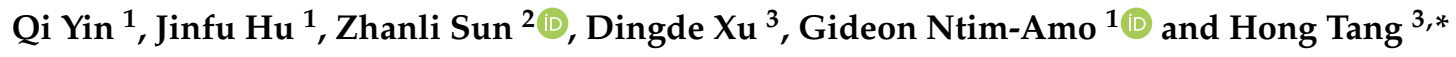 \\ 1 College of Management, Sichuan Agricultural University, Chengdu 611130, China; yinqi@sicau.edu.cn (Q.Y.); \\ hjf414@stu.sicau.edu.cn (J.H.); ntimamogideon@stu.sicau.edu.cn (G.N.-A.) \\ 2 Leibniz Institute of Agricultural Development in Transition Economies (IAMO), \\ 06120 Halle (Saale), Germany; sun@iamo.de \\ 3 Sichuan Center for Rural Development Research, College of Management of Sichuan Agricultural University, \\ Chengdu 611130, China; dingdexu@sicau.edu.cn \\ * Correspondence: tanghong@sicau.edu.cn; Tel.: +86-153-9007-9725
}

Received: 13 October 2020; Accepted: 18 November 2020; Published: 21 November 2020

check for updates

\begin{abstract}
Massive and rapid urbanization has led to population loss in rural areas, particularly in emerging and developing countries like China. As a result, houses in rural areas become vacant, and the house prices in cities, at the same time, skyrocket. While the research on the vacant farmhouses market (VFM) is a pressing issue for sustainable urbanization and has profound policy implications in China, few empirical studies have been conducted on analyzing the willingness of house owners and urban residents to participate in the VFM and any influencing factors-as there is no such operating market in China. To bridge the research gap, we first conducted a questionnaire-based survey on rural households and urban residents with a random sampling method in six cities in Sichuan Province, China. A total of 571 valid samples, including 284 rural households and 287 urban residents, were obtained. Based on these survey data, we then used logistic regression to estimate the influencing factors on the willingness of house owners and urban residents in renting in/out or selling/buying vacant farmhouses. The results showed that: (1) more than $60 \%$ of rural house owners and urban residents are willing to participate in a potential VFM; (2) the main influencing factors of house owners' willingness to rent out or sell their houses include the sociodemographic characteristics of farmers (e.g., age, household income) and characteristics of the vacant houses (e.g., distance to the main roads, the status of vacant houses), while the major factors that affect the willingness of urban residents to rent in or purchase vacant rural houses are the sociodemographic characteristics of urban residents themselves (e.g., occupation), the status of the potential houses, and the perceived housing market; (3) most farmers want a regulated platform for the vacant farmhouses; urban residents pay more attention to the good natural environment in rural areas and the infrastructure and public service levels of vacant farmhouses in rural areas. This study thus showed the necessity, feasibility, and potential challenges and barriers involved in establishing a VFM in China.
\end{abstract}

Keywords: vacant farmhouse market (VFM); rural housing market; willingness analysis; households survey; rural development

\section{Introduction}

Fast economic development is often accompanied by rapid urbanization or rural-urban migration in developing countries. In the past 40 years, Chinese rural areas and agricultural production have witnessed substantial progress with neck-breaking speed ever since the implementation of the Reform and Opening-up Policy in the late 1970s. However, urbanization and industrialization have also had a detrimental impact on rural development [1-3]. With the non-agriculturalization of rural populations, 
hollowed villages, environmental pollution, and increased poverty, a series of "rural problems" have emerged [2]. As urbanization progresses, massive numbers of rural residents migrate into large and coastal cities [4-6]. Most of these people work and live in cities, even without holding an urban hukou (a residential registration system in China), while leaving rural homesteads in the countryside. As a result, many rural houses stay vacant, leading to a serious waste of land resources. Simultaneously, the development of urbanization has brought a series of problems to cities themselves. For example, water pollution, air pollution, and solid waste pollution in cities have become increasingly prominent, which has affected the regular lifestyle of urban residents [7-11]. Congested traffic, skyrocketing housing prices, and a shortage of public services (e.g., schools, hospitals) are causing adverse impacts on the welfare of urban residents. These phenomena are prevalent throughout the world, especially in fast-developing countries like China.

Many countries are expanding their cities to boost their economies and living standards [4]. The proportion of people living in urban areas around the world rose from 33\% in 1960 to $54 \%$ in 2016, with particular growth in Asia and Africa [12] and in North America and Europe, more than three-quarters of the population already live in urban areas; urban areas are growing and expanding [13]. The ever increasing and expanding of urban areas and the population was often accompanied by emigration and depopulation of rural areas, as well as the abandonment of farmland and rural houses. These empty farmsteads, the half-filled factory, the vacant storefronts, and the threadbare homes are all too familiar in the postindustrial heart of the United States [14]; Some central and eastern European countries, such as Poland, also experienced a continuing dip in agricultural productivity and agricultural employment, and this process was followed by migration, urbanization, and modernization of housing [15]. The vacant farmhouses become a big waste of assets as well as resources, while also hindering rural development.

On the other hand, rapid and overextended urbanization may lead to a stressful life in urban conglomerates due to long commutes, traffic congestions and accidents, severe air and water pollution, high crime rate, stress, and the squalor of slums [13]. As one of the largest developing countries, India, for example, has been suffering from severe problems such as the development of slums, pollution, and noise issues during the process of urbanization [16]. In recent decades, due to these serious "urban diseases, " many urban residents have started to show a desire to live in the countryside. Many medium-high income citizens opt to move from metropolitan areas to suburban or even rural areas. This urban-rural migration, or so-called ex-urbanization, has been widely observed in developed countries, like in the United States of America. Alternatively, citizens sometimes choose to buy or co-own a second house in rural areas. In Finland, for example, rural second home tourism has become a fundamental part of the country's cultural identity and modern life [17]. This trend is also emerging in developing countries such as China, where middle- and high-income citizens show great interest in living in rural areas or purchasing a second or weekend houses in rural areas. Additionally, thanks to the widespread use of the internet, many people can work remotely, e.g., from home. The COVID-19 pandemic further strengthened the work-from-home trend.

The situation involving vacant farmhouses and "urban diseases" is especially worrisome in China. Massive rural-urban migration has created demographic problems. The rural population decreased from 790 million in 1978 to 570 million in 2018 [18]. While the rural population has been reducing substantially, the total area of China's villages is expanding at the cost of fertile cropland despite the scarcity of farmland in China. For example, from 1990 to 2016, the total villages area did not decrease with the dropping of the rural population; instead, this population increased by about 2.52 million hectares [19]. This perplexing phenomenon is a direct result of two things. Firstly, the migration of a large number of rural populations to cities has left many dwellings in the village unoccupied either seasonally or permanently [1]. Secondly, new modern houses are continued to be built on the village's periphery, often at the expense of fertile farmland, to get bigger homesteads without demolishing the old houses that are usually characterized by smaller homesteads and basic building materials [20]. The underlying reason for these trends is that most rural migrants face difficulties completely settling 
down in cities due to the barriers they face, such as not holding the relevant hukou. Working and living in cities do not automatically entitle them to an urban hukou; thus, they cannot enjoy the same benefits in education, healthcare, and social security as urban citizens with an urban hukou [21,22]. In addition, many rural migrants do not have a permanent job and lack job security. They are not entirely urbanized even though they live in cities for a long time. Consequently, the migrants still want to keep their rural houses and even build new ones even if they do not need to live there. In other words, those rural houses serve as a form of social security [23]. In some cases, migrants may have an urban hukou or simply want to sell their rural houses. However, there is little demand within the village in such cases, as rural construction lands are collectively owned and rural houses can only be exchanged within the village. Thus, these migrants cannot capitalize on the potential economic value of their rural houses and improve their life in the city through transactions [24]. Ultimately, this is indirectly caused by the lack of a functioning rural housing market and institutional barriers, like the hukou system.

In big cities, on the other hand, the issues of traffic congestion [25], haze [26-28], soaring housing prices [29], and food safety concerns [30,31] are becoming increasingly prominent in China. Concurrently, the travel time between urban and rural areas has been shortened due to the fast development of transportation infrastructure such as highways, high-speed railways, subways, and light rail, in recent years. These developments facilitate the daily commute of urban residents living in rural areas, as well as shorter commutes for activities such as business meetings and leisure trips [32]. As a result, more and more urban residents wish to move to the countryside for better traffic conditions, fresher air, cheaper houses, safer food, and a quieter environment. However, China has not yet established a rural vacant farmhouse market because the collectively-owned rural homesteads can only be used by members of collectives and cannot be transferred outside the original collective, i.e., urban residents. Nevertheless, lured by significantly lower housing prices in rural areas, urban residents in some cities buy or rent rural homesteads and rural houses under informal transactions—strictly speaking, these are illegal transactions [33].

Given the profound scientific and policy implications of these developments, the homesteads and vacant rural houses in rural China have attracted increasing attention from international researchers. The homestead here refers to the construction land allocated to rural residents by the collective community, i.e., the village, for building self-used rural houses. While rural houses on top of the homestead are private properties, the homesteads, which are the lands that houses are built on, are collectively owned. This unique tenure system hinders the formation of the rural housing market. Most of the current studies address homestead withdrawal (i.e., giving up the homesteads), homestead transfer, and the institutional systems of rural homesteads (e.g., tenure settings). For example, a study analyzed factors that affect farmers' willingness to withdraw (or give up) homesteads in Zhejiang Province. The research showed that farmers are reluctant to give up their homesteads due to the concerns regarding employment risk, lack of social security, the high cost of new houses, low compensation for homesteads, the decline in the standard of living, and inconvenience in agricultural production. The authors thus argued that employment support and social security provision are the keys to enabling the farmers to give up their homesteads [34]. In terms of homestead transfer, a study on Shenzhen's reforms that allow collective-owned rural land transactions in the open market found that the dual-track land administration system, that is, the state manages market transactions, has led to many social problems, such as urban construction land scarcity, the inefficiency of land resource allocation, and exacerbated social injustice [35]. Another study explored the advantages and disadvantages of the existing rural homestead transfer models through comparative analysis and proposed a new rural homestead land transfer system under collective ownership. This research provides a clear direction for rural homestead land transfers [36]. As for the institutional setting of the rural homestead system, Zhou et al., studied the evolution of China's land system, analyzed the main problems and new challenges in China's land system, discussed the current specific measures used to deepen China's land system reform, and pointed out that the development direction of China's rural land system reform is to make the property rights relationship clearer, the farmland rights more 
complete, the transfer transactions more market-oriented, and the property rights' protection more equal [37]. Some studies that commented on the new Law of Land Management in August 2019, discussed the potential challenges that the country may face in revitalizing rural areas and called for further institutional innovation in rural land system reform. The proposal is that the rural residential land acquired for a fee can be freely transferred or converted [38]. The above-mentioned related studies have introduced some basic conditions, theoretical discussions, and typical cases of China's rural homesteads to the international academic community. These studies are related to the potential rural housing transactions; however, there are relatively few studies on the construction of China's rural housing market, especially in international journals.

To bridge this research gap, we focus on the potential demand and supply of vacant rural houses. In any market, transactions only happen when the supply matches the demand, implying an acceptable price for both suppliers and buyers. While the real estate market in cities of China has been functioning ever since the reform of commercialization of urban housing in the 1990s [39], there is not yet a functioning vacant farmhouse market in China. To assess the potential formation of the vacant farmhouse market (VFM), we need to first investigate whether there are enough suppliers and demanders who are willing to sell or buy farmhouses, and then what kind of products are needed and what is the acceptable price. The farmers who own vacant farmhouses are the possible suppliers while the citizens who are willing to live in the countryside are the possible demanders. Therefore, in this research, we studied whether there are enough suppliers, i.e., owners of the vacant farmhouse, and demanders, urban residents who are willing to live in the countryside, and what kind of products, i.e., farmhouses, are needed and planned to conduct further study on the acceptable price in the future. Thus, we specifically examine the willingness and influencing factors of house owners and urban residents involved in rural house transactions. To do this, we conducted a questionnaire-based survey on randomly selected rural housing owners and urban residents in Sichuan Province, China. With these survey data, we used logistic regression to assess the influencing factors of the willingness of these transaction participants. Based on the empirical analysis result, we then assessed the necessity and feasibility of establishing the VFM. We further put forward advice for the government to formulate related policies in the future in supporting the VFM.

The rest of the paper is constructed as follows. Section 2 describes the institutional and legislative framework on the property and rights of rural housing, the study area, and the data survey. Section 3 briefly introduces the data and methods used in the analysis. In Section 4, we present the analysis of farmers' and urban residents' willingness to participate in VFM and its influencing factors and discuss the empirical analysis results. Section 5 concludes with a summary of the main results of this research, policy implications, and future research.

\section{Study Area and Data Source}

\subsection{Institutional and Legislative Framework on the Property and Rights of Rural Housing}

Given the unique setting of the rural housing tenure system in China, as we already mentioned in the Introduction, it is necessary to further describe the tenure system of rural houses and related institutions. China is a society with a dual structure of urban and rural systems for people and lands: residents are in general classified as rural residents and urban residents according to the household registration system, widely known as the hukou system [22]; while urban land is state-owned, rural land is collectively-owned by villagers living in the same community, i.e., villages. Therefore, the land management agency has adopted different management and governing regulations for urban and rural areas [40]. Compared with urban construction land, which is given full land rights, including possession, use, income-generating, and disposal, rural construction lands including rural homesteads have limited property rights and are heavily restricted by relevant laws [41]. According to China's Constitution and Land Management Law, rural land, including farmhouses, is owned by rural collectives and prohibits homestead transfer outside of the collective. Therefore, only members of the 
collective can use and manage collective land [42]. The current complicated and unreasonable land tenure system inhibited the formation of the rural housing market. This in turn leads to the idleness of an increasing number of vacant houses, which is exacerbated by the demographic changes caused by the rural-urban migration and the low fertility rate. Farmers are, unfairly, being deprived of the chance to generate income from these vacant assets, renting them out, or selling them.

In recent years, the Chinese government has embarked on the reform of the homestead system to revitalize the vacant land resources in rural areas. There are four main tasks in the reform of the homestead system, i.e., reforming the way to protect and obtain the rights and interests of the homestead, exploring the system of paid use of homestead, and the mechanism of voluntary withdrawal and improving the management system of the homestead. Since 2015, the government has carried out rural "three pieces of land" (i.e., agricultural land, rural operational construction land, and homesteads) reforms to regulate farmland acquisition for construction, market entrance of collective operational construction land, and homestead management system, in 33 cities and counties across the country from 2015 to 2018. These pilot areas were allowed to remove some restrictions on rural land in the Land Management Law and the Urban Real Estate Management Law.

At the same time, the No.1 document of the CPC Central Committee in 2018 further clearly stated that the "Separation of three rights (the rural homestead collective land ownership, the qualification rights for homestead allocation, and the homestead land use rights) in homestead" should be explored. Moreover, the rural homestead collective land ownership should be implemented, and the qualification rights for homestead allocation and the farmer house property rights for homestead should be ensured, and the homestead land use rights and farmer house use rights should be moderately released, step by step. In 2019, China's "Land Management Law" has officially stipulated that China's non-agricultural construction land will have the same rights as the state-owned urban land, clearing up the legal barriers to the entry of collectively operated construction land into the market. This means that in the near future, China will likely establish a pilot for the VFM, and the research will hopefully provide a certain reference value for the pilot construction.

\subsection{Study Area}

Sichuan Province is located upstream of the Yangtze River in southwestern China. It covers 486, $052 \mathrm{~km} 2$ and has a population of 81.07 million, of which 44.67 million are engaged in agricultural production [43]. The total labor force of Sichuan in 2013 was 64.39 million, of which 33.68 million were rural laborers [43]. Statistical data shows that in 2014, the number of migrant workers in Sichuan Province reached 24.723 million, making it the country's largest labor exporting province. In rural areas of Sichuan, especially remote areas, the problem of rural labor loss is prominent, and most of the people left behind in the countryside are lonely old people and left-behind children. A large predominately young and middle-aged labor force has been transferred to the cities, and a large population migration has caused vacant rural housing and other problems. Data show that in many rural areas of Sichuan province, the vacant rate of farmhouses is close to $40 \%$ [44]. Therefore, rural real estate waste is particularly serious in Sichuan Province, compared with in other provinces, making it a good example for studying farmers' and urban residents' willingness to participate in VFM.

\subsection{Sampling Strategy}

We adopted a stratified random sampling design: we first selected six cities from the strata defined by the level of urbanization and economic development in Sichuan Province. Thus, the survey samples can representatively reflect the general situation of the entire Sichuan Province. From each city, we tried to randomly sample 50 house owners and 50 urban residents to fill out the questionnaires through face-to-face interviews. In doing so, we strived for a decent sample size for the later regression analysis. We largely followed the rules of thumb proposed by Green (1991) in estimating the necessary sample size for regression analysis to ensure there was adequate statistical power $[45,46]$. 
To implement the stratified random sampling, first of all, we divided the 21 cities in Sichuan Province into three categories according to the level of socioeconomic development, i.e., developed, moderately developed, and less developed. Among the developed cities, we randomly selected one city; among the moderately developed cities, we randomly selected three cities; and among the underdeveloped cities, we randomly selected two cities. As a result, the 6 cities, including Leshan (developed), Yibin, Ya'an, Suining (moderately developed), Nanchong, and Dazhou (less developed), were selected. The results are shown in Figure 1 and Table 1 . The reason why we only selected one city among the developed cities and three among the moderate cities, instead of two from each group, is that this largely reflects the coherent structure of cities in terms of development level-this ensures the representativeness of the sample data. Among the 21 cities of Sichuan province, there are 11 middle-income while only 5 of 21 were developed and less developed cities, respectively. After the six cities were selected, we randomly chose three to six villages in each city and finally got 24 villages out of these six cities.

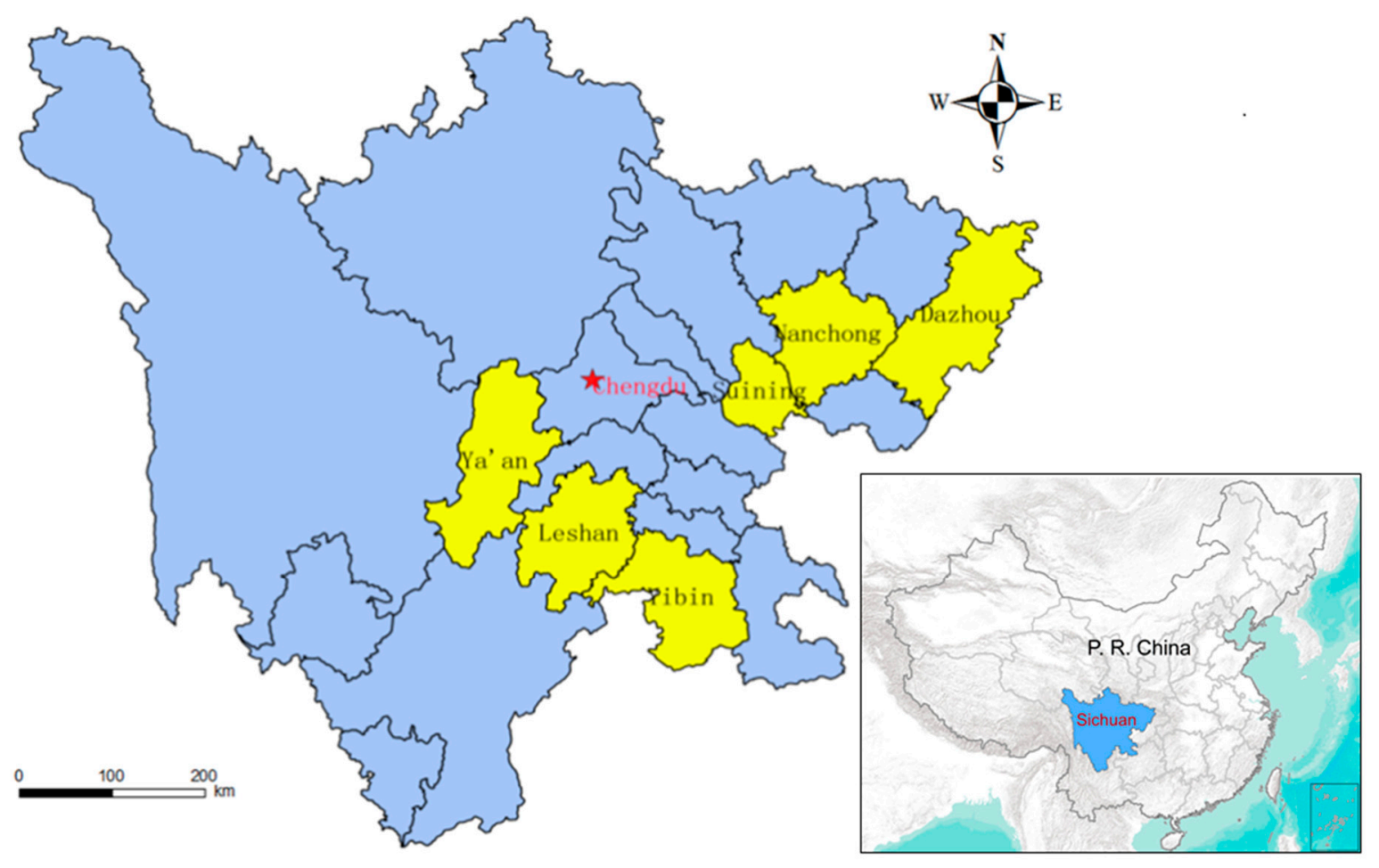

Figure 1. The study area.

Table 1. The grouping of cities in the study area according to economic development level.

\begin{tabular}{ccccccc}
\hline \multirow{2}{*}{$\begin{array}{c}\text { Economic Development Level by } \\
\text { Real GDP per Capita(¥) }\end{array}$} & $\begin{array}{c}\text { Developed City } \\
\mathbf{> 4 5 , 0 0 0}\end{array}$ & \multicolumn{2}{c}{$\begin{array}{c}\text { Medium-Developed Cities } \\
\mathbf{3 5 , 0 0 0 - 4 5 , 0 0 0}\end{array}$} & \multicolumn{2}{c}{$\begin{array}{c}\text { Less Developed Cities } \\
<35, \mathbf{0 0 0}\end{array}$} \\
\cline { 2 - 7 } & Leshan & Yibin & Ya'an & Suining & Nanchong & Dazhou \\
\hline Real GDP per capita & 49,360 & 44,732 & 42,015 & 37,745 & 31,271 & 29,707 \\
\hline
\end{tabular}

Note: The data are from the real GDP per capita of the cities in Sichuan Province in 2018.

\subsection{Survey Design and Data}

The survey includes questionnaires from two groups. One group is the house owners, i.e., the owners of the vacant farmhouses. Thus, in this paper, sometimes we also refer to house owners as "farmers." The other group is the urban residents, i.e., randomly selected urban residents who could be the potential buyers or the tenants of the vacant farmhouses. In the vacant farmhouse market, the house owners act as the suppliers, while the urban residents act as the demanders. 
Therefore, the questionnaire was designed based on previous relevant studies. It contained five parts: Part 1 is about the respondent's age, marital status, occupation, etc. Part 2 concerns the family situation of the respondent. Part 3 is about the basic situation of the vacant farmhouses for farmers and current housing conditions for urban residents. In Parts 4, we asked respondents about their understanding and perception of the rural homestead market. In the last part, i.e., Part 5, the respondents were asked about their willingness to participate in vacant real estate purchases in rural areas. The influencing factors and their importance were obtained through logistic analysis using data from the questionnaire.

It is noted that, in this paper, a "vacant farmhouse" refers to the completely vacant houses, instead of houses which have some vacant rooms. Also, the "vacant farmhouse market" includes both purchasing and renting these farmhouses. Because this market is quite undeveloped at present we believe both purchasing or renting can improve the utilization of these vacant farmhouses. Also, it is quite complicated if at all possible to buy or sell rural houses, as we explained earlier. So, during the interview, we asked the interviewees what their willingness was to buy/sell or rent in/rent out vacant farmhouses. In other words, we did not differentiate between the willingness to purchase or rent. A purchase in the future VFM was merely defined as a long-term "rental" unless the land tenure system would be completely reformed.

The survey was carried out and completed within two weeks in August 2016. As for the survey on house owners, we randomly selected 3-6 villages within each city. Some of these randomly chosen villages only have several vacant farmhouses, while some others may have up to 20 vacant houses. Since we aimed to survey the owners of vacant farmhouses, we could not expect to meet the owners by visiting these vacant houses. To solve this problem, we visited the village heads first in each village because, in China, the village heads generally know the situation for all the villagers and know how to contact them. From the village heads, we got to know how to find the house owners. For the house owners who have bought houses in the towns nearby, we visited their new houses and conducted interviews. For other house owners who were working in other provinces or could not be found in their new houses, we conducted the survey via telephone calls. The survey for urban residents was much easier. We went to these six cities and randomly selected 50 persons in each city to carry out the survey.

Data were firstly recorded on paper, then inputted into a computer database, and then cleaned for statistical analysis. A total of 600 questionnaires were distributed, of which 300 were house owners and urban residents, respectively. A total of 571 valid questionnaires were retrieved: 284 house owners and 287 urban residents with an effective response rate of $95.2 \%$.

\section{Method}

\subsection{Model Selection}

In terms of research methods, previous research employs a wide range of models such as genetic algorithms [47-50], multi-criteria analysis [50-52], data-driven technology [53-55], and econometrics to study the real estate market and the real estate industry. Willingness analysis is the most important part of the empirical study of this paper. For that, the logistic model has been considered as one of the most suitable methods. For example, logistic regression has been used to study the willingness to buy houses [56], the willingness of farmers' homesteads to transfer property [57], and other related studies $[58,59]$. Therefore, we chose the logistic model as the main statistical model. Among the several logistic models such as Ordered logistic regression, Multinomial logistic regression, and Stereotype logistic regression, we chose Stereotype logistic regression because, in our questionnaire, we used not only "yes" or "no" as the choices of their willingness, but also a third choice as "not sure, " and Stereotype logistic regression is primarily used when you are unsure of the relevance of the ordering of the outcome [60]. 


\subsection{Variable Design}

Through the analysis of willingness and its influencing factors, suggestions can be made for policymakers to cultivate this new market. From the perspective of house owners, the dependent variable is "willingness to sell or rent vacant farmhouse, " the variable name is abbreviated as "willingness to sell"; from the perspective of urban residents, the dependent variable is "willingness to buy or rent rural houses, " the name of the variable abbreviated as "willingness to buy." The independent variables of the respondents, which include house owners and urban residents, are mainly divided into four categories, including the individual characteristics of the respondents, family characteristics, house characteristics, and the cognition of vacant farmhouse. See Appendix A for details on the variable design.

\section{Results and Discussion}

\subsection{Willingness Analysis}

\subsubsection{Willingness Analysis for House Owners}

The house owners' willingness to participate in VFM is shown in Figure 2.

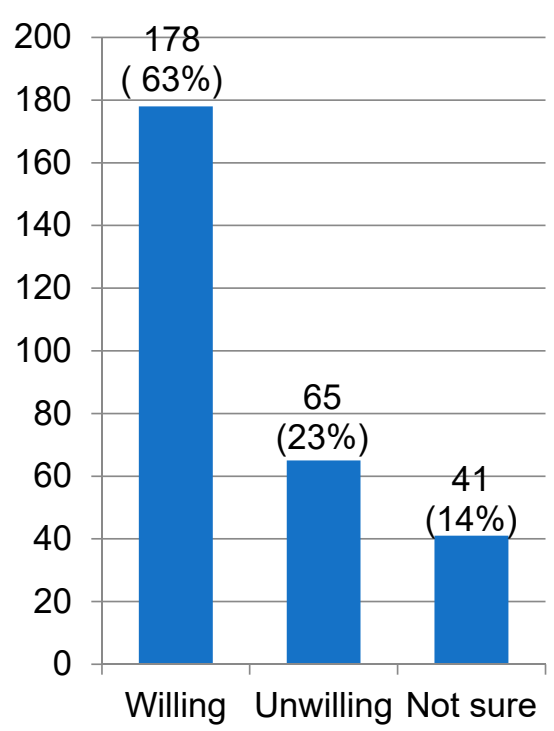

(a)

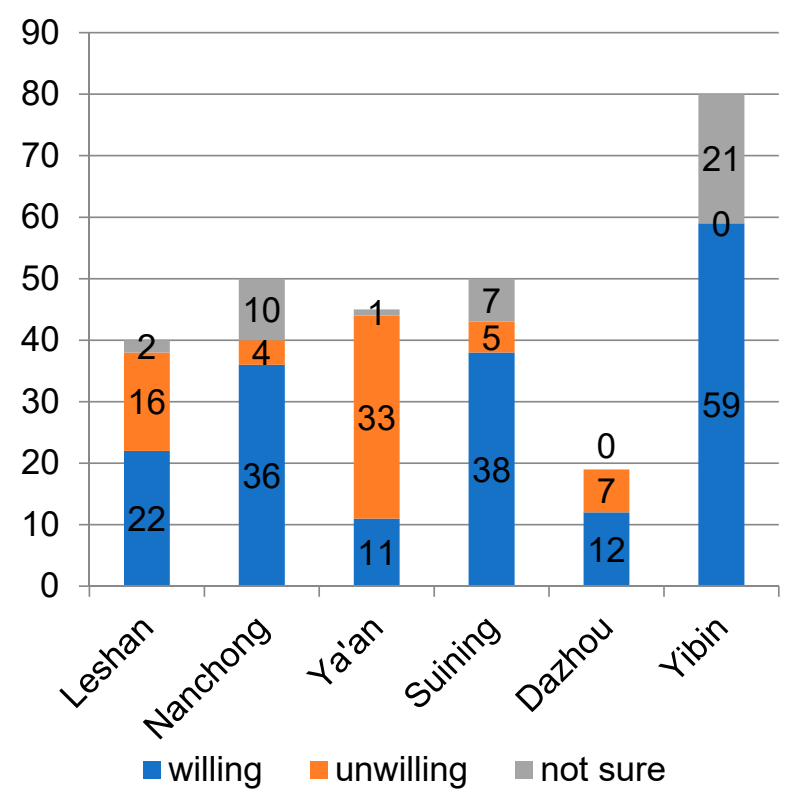

(b)

Figure 2. House owners' willingness to participate in the vacant farmhouse market. (a) House owners' willingness: total; (b) House owners' willingness: different cities.

In general, the willingness of house owners to participate in VFM is very strong-63\% of the house owners interviewed expressed a willingness to sell/rent out vacant houses. In most cities, the proportion of house owners willing to participate in VFM is much higher than the number that was not willing to do so, especially in Nanchong, Suining, and Yibin. However, Ya'an is an outlier. Unlike other places, most house owners in Ya'an city are unwilling to sell or rent their houses, which is unexpected. This can be explained by the fact that many of the interviewees in Ya'an city are older people. Some of them are emotionally attached to their old houses and would not sell or rent them; some others, however, think that their old farmhouses are in poor condition (very broken) or far from the town, meaning no one would like to buy or rent their houses. Even after we explained to the interviewees that they do not need to consider whether anyone would buy or not and they only need consider their own willingness to sell, the old farmers insisted on thinking since no one would buy, they would not 
sell or rent. This result, to some extent, reflects the Ya'an farmers' characteristics of being anxious and their strong sense of humbleness resulting from their age, their status of being farmers, and the poor condition of their houses. Their anxieties became an important factor which influences their own decisions. Also, another important factor is that, in some places where the land market or housing market has not yet been established, and transactions are rare, no one can see the practical benefit of renting out or selling a vacant farmhouse, so they are not willing to participate in this market; as long as this market is established and there are some successful examples of vacant farmhouse transaction, there will be followers. This is the power of examples.

\subsubsection{Willingness Analysis for Urban Residents}

The urban residents' willingness to participate in VFM is shown in Figure 3.

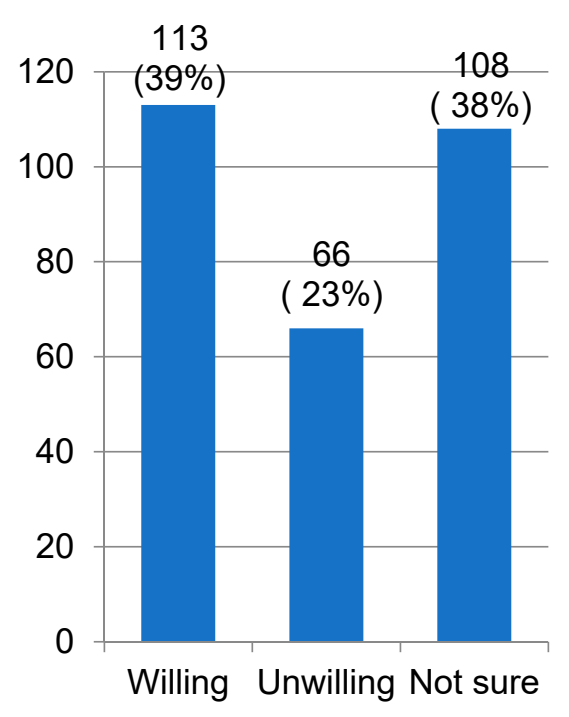

(a)

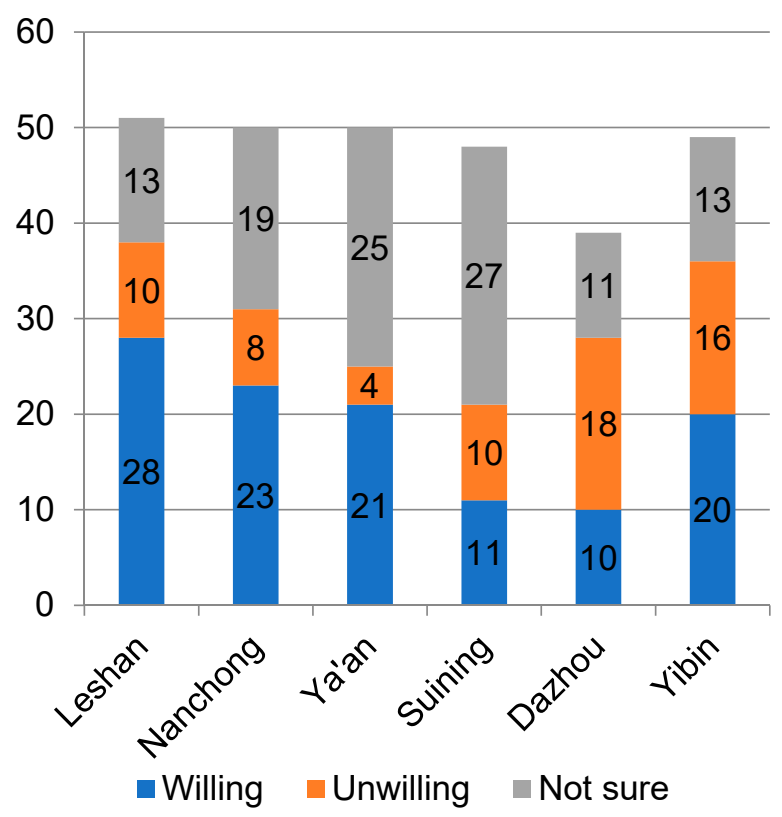

(b)

Figure 3. Urban residents' willingness to participate in the vacant farmhouse market. (a) Urban residents' willingness: total; (b) Urban residents' willingness: different cities.

For urban residents, the proportion of people who are willing to participate in VFM is significantly higher than those who are unwilling to participate. However, compared with house owners, the willingness percentage for the house owners is $63 \%$, while it is only $39 \%$ for urban residents. The $24 \%$ gap lies in the "not sure" group. It seems the house owners are much more certain about their attitude toward their willingness to sell, while many urban residents seem to be uncertain. There could be a few reasons for this. First, many urban residents may never think about this issue because a farmhouse in the countryside is not a necessity for them. Second, the decisions of urban residents depend on many factors, such as the location of the house, the infrastructure, the condition of the house; however, for the house owners, they only need to be sure they want to sell or rent out the house, no matter who will be the customer. Therefore, urban residents have many more factors to consider than the house owners, so that they are much more uncertain about this behavior than the house owners.

Dazhou city has a large share of unwilling urban residents. The main reason for this is that many interviewees are new immigrants from rural areas; they would not want to go back to the countryside and live a countryside life. Furthermore, the reason why residents are less willing to sell compared to in other cities is that Dazhou has a relatively faster speed of urbanization [61], there are also more newly built houses in the city, and farmers in this city are more likely to buy houses in the city. Hence, the possibility of meeting with new immigrants on the street is higher there than in other cities. 


\subsubsection{Matching Analysis between House Owners' and Urban Residents' Willingness}

The house owners' willingness and urban residents' willingness in each city were compared to show whether they match well. The results are shown in Figure 4.

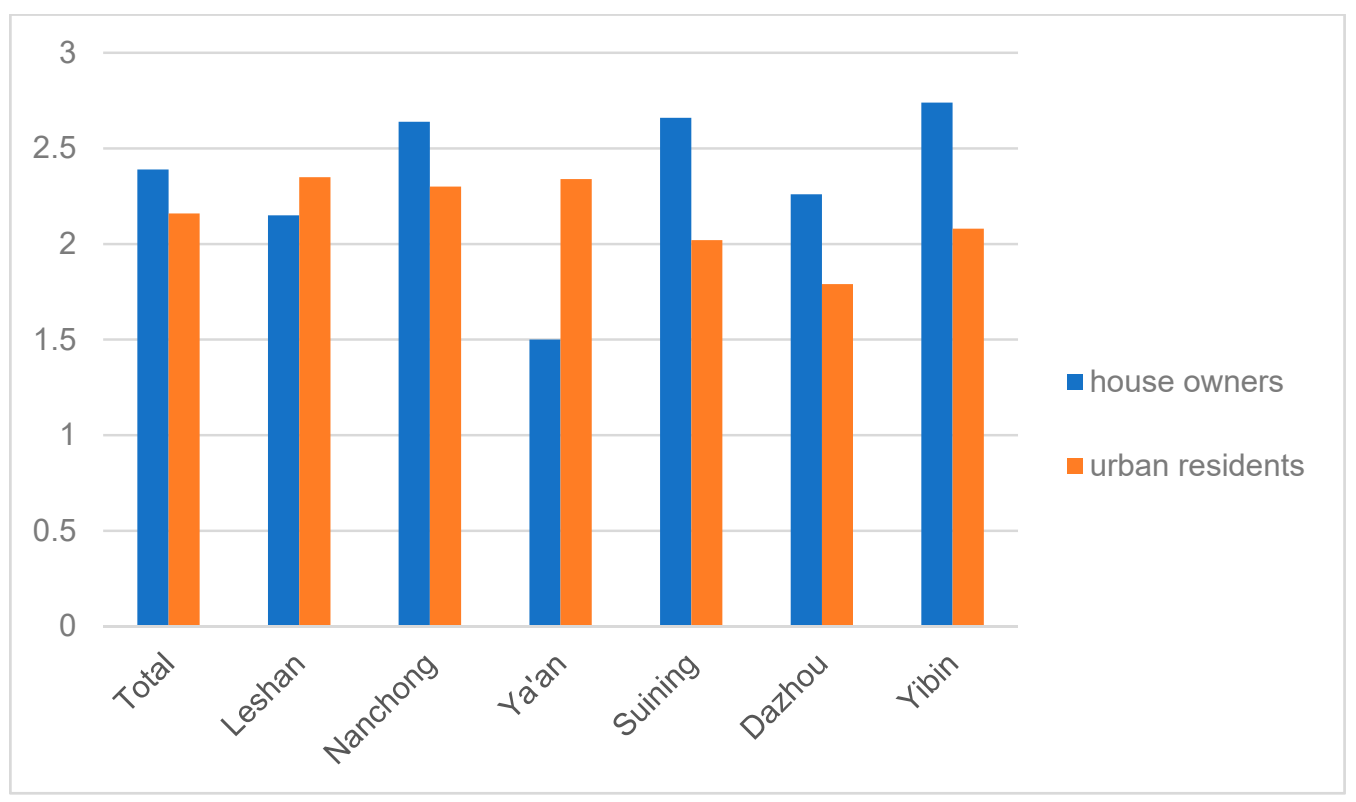

Figure 4. Matching analysis between house owners' willingness and urban residents' willingness.

As a whole, both the willingness of house owners and urban residents is higher than 2, and there is no obvious gap between urban residents' willingness and house owners'. That means, generally, a large proportion of urban residents and house owners are willing to transact with vacant farmhouses. The willingness of both sides is also roughly equal. However, for different cities, the situation is different. The cities whose means of willingness are lower than 2 need further in-depth analysis. Also, those cities whose willingness level varies between urban residents and house owners should also be closely studied.

Thus, Ya'an city is a special case. The willingness of the house owners to sell in this city is lower than 2 , which has been mentioned previously, and the mismatch between urban residents and house owners is obvious. In this case, it is not wise to encourage the establishment of a vacant farmhouse market because the supply and demand do not match well there.

The willingness gap between urban residents and house owners in Dazhou and Suining is also relatively large, but the willingness for both urban residents and house owners is higher than 2 , so it is still possible to establish a vacant farmhouse market in these cities.

\subsubsection{Other Findings}

Other Findings from the House Owners' Responses

The house owners' are divided into two parts: willing and unwilling. For the willing house owners', we first discussed their expected vacant farmhouse circulation form and the management of vacant farmhouse. Second, we explored whether they think the existing system is reasonable and what they think needs improvement.

For the house owners' who are unwilling, we mainly discuss the reasons for their unwillingness.

From Table 2, 34.9\% of the house owners are willing to choose to direct transactions between buyers and sellers, but $39.4 \%$ of the house owners chose for the government to organize circulation, and $23.2 \%$ of the house owners' chose for the village committee to organize circulation. To a certain extent, this indicates that a total of $62.6 \%$ of the house owners want an organized circulation. This is because 
most of China's current farmers are not highly educated, and they are cautious about the circulation of real estate. Thus, they believe that organized circulation is a more secure way of circulation. Similarly, when farmers choose the management method of vacant houses, $65.5 \%$ of these farmers think that this option is necessary for unified management and concentrated construct of the building. This also shows that when farmers manage a farmhouse, they hope that the government can organize farmhouse management because they believe that under unified management, the management of their farmhouse will be more secure.

Table 2. Which agencies would direct the market and how this would occur.

\begin{tabular}{cccccc}
\hline & $\begin{array}{c}\text { Through } \\
\text { Farmers' } \\
\text { Spontaneous } \\
\text { Circulation }\end{array}$ & $\begin{array}{c}\text { The } \\
\text { Government } \\
\text { Organizes the } \\
\text { Circulation }\end{array}$ & $\begin{array}{c}\text { The Village } \\
\text { Committee } \\
\text { Organizes the } \\
\text { Circulation }\end{array}$ & $\begin{array}{c}\text { Through } \\
\text { INTERMEDIARIES }\end{array}$ & Others \\
\hline Sample Size & 99 & 112 & 66 & 4 & 3 \\
The percentage & $34.9 \%$ & $39.4 \%$ & $23.2 \%$ & $1.4 \%$ & $1.1 \%$ \\
\hline
\end{tabular}

From Table 3, $62.7 \%$ of house owners believe that the current rural land system has unreasonable aspects. The main reason for this is, as mentioned above, more and more rural farmhouses are vacant, and farmers expect to realize the economic benefits of vacant farmhouses by selling or renting. However, due to the obstacles of the current rural land system, these actions cannot be legalized. This shows that reform of China's rural land system is imminent. In addition, most farmers' needs are related to real estate circulation, which indicates that farmers have a strong demand for the marketization of vacant housing, which indicates that it is time to establish VFM. Refer to Table A3 in the Appendix A for further details.

Table 3. Farmers' views on the need for centralized management of vacant homesteads and whether the current system needs to be improved.

\begin{tabular}{ccccc}
\hline & \multicolumn{2}{c}{ A } & B \\
\cline { 2 - 5 } & Sample Size & The Percentage & Sample Size & The Percentage \\
\hline Very necessary & 40 & $14.1 \%$ & 67 & $23.6 \%$ \\
Necessary & 146 & $51.4 \%$ & 111 & $39.1 \%$ \\
Not necessary & 58 & $20.4 \%$ & 58 & $20.4 \%$ \\
It doesn't matter & 40 & $14.1 \%$ & 48 & $16.9 \%$ \\
\hline
\end{tabular}

Note: $\mathrm{A}=$ Whether it is necessary to have unified management and construct a building in a concentrated way; $\mathrm{B}=$ Whether it is necessary to improve the current related system.

For unwilling house owners', the main reason why most people are reluctant to participate in the VFM is that their current house is useful for them, because this group of people usually use these vacant farmhouses when they return to visit relatives during traditional Chinese festivals. However, this part of the population is a potential willing person. When their relatives in the village move out or die, the maximum value of the vacant farmhouse will be lost. House owners who are not willing to participate may change their attitudes to selling after this occurs. Refer to Table A4 in the Appendix A for further details.

\section{Other Findings from the Urban Residents' Responses}

We divided the urban residents into two groups: the willing residents (who expressed a willingness to buy vacant houses) and the unwilling residents (who have no willingness to buy vacant houses). For the willing urban residents, we explored what the most important aspects are to them, such as what kinds of infrastructure are most important. In addition, we studied their purpose for buying renting farmhouses and discussed the reasons that lead to their unwillingness and the obstacles they think are developing in this market. 
The main reasons for urban residents to buy or rent farmhouses are shown in Table 4 . With the deterioration of air quality in big cities in recent years, urban residents have become increasingly worried about this issue. Of the 113 urban residents, 72 urban residents chose "fresh air and better environment" as the main reason they want to buy or rent farmhouses, accounting for $64 \%$ of the responses as the main reason. Only $5 \%$ of urban residents chose other factors, which indicate that poor air, food safety, noise, and traffic jams are the main worries for urban life, compared with life in the countryside.

Table 4. The main reasons for urban residents to buy or rent farmhouses.

\begin{tabular}{cccccc}
\hline & $\begin{array}{c}\text { Fresh Air and } \\
\text { a Better } \\
\text { Environment }\end{array}$ & $\begin{array}{c}\text { Exercise, Safer } \\
\text { Fruits and } \\
\text { Vegetables }\end{array}$ & $\begin{array}{c}\text { No Traffic } \\
\text { Jams }\end{array}$ & Quietness & $\begin{array}{c}\text { Other } \\
\text { Factors }\end{array}$ \\
\hline Ranked first & 72 & 15 & 8 & 12 & 6 \\
Ranked second & 2 & 15 & 5 & 17 & 0 \\
Ranked third & 0 & 0 & 5 & 7 & 1 \\
Total & 74 & 30 & 18 & 36 & 7 \\
\hline
\end{tabular}

As shown in Table 5, transportation ranks first among all of the relevant types of infrastructure. A total of 81 respondents mentioned it, and 70 of them considered it to be the most important factor. Rural areas are usually far from a city, and most of the urban residents have jobs or businesses in the cities. Convenient transportation (e.g., near the highway exits or close to light rail stops) can potentially enable urban residents to live in rural areas and enjoy a high-quality rural environment while working in the cities.

Table 5. The most important conditions expected by urban residents.

\begin{tabular}{cccccccc}
\hline & $\begin{array}{c}\text { Convenient } \\
\text { Transportation }\end{array}$ & Tap Water & $\begin{array}{c}\text { Natural } \\
\text { Gas }\end{array}$ & $\begin{array}{c}\text { Electric } \\
\text { Power }\end{array}$ & $\begin{array}{c}\text { The } \\
\text { Internet }\end{array}$ & $\begin{array}{c}\text { Mobile } \\
\text { Phone } \\
\text { Signal }\end{array}$ & Others \\
\hline Ranked first & 70 & 16 & 6 & 6 & 10 & 3 & 2 \\
Ranked second & 7 & 41 & 15 & 22 & 9 & 8 & 2 \\
Ranked third & 4 & 10 & 30 & 25 & 7 & 7 & 1 \\
Total & 81 & 67 & 51 & 53 & 26 & 18 & 5 \\
\hline
\end{tabular}

In Table 5, tap water ranks second. A total of 67 respondents mentioned it, and 41 of them considered it to be an important factor. Water is the source of life, and as a necessity in people's daily life, it is a must for every property. Many rural areas in Sichuan do not have tap water. Water quality and safety cannot be guaranteed in these regions. It is not convenient to lack tap water. Thus, urban residents put tap water high on the list.

Internet and mobile phone signals are also mentioned but had relatively minor importance (see Table 5). This does not mean the internet and communication are not important to these residents. The Internet and $4 \mathrm{G}$ networks have been widely accessible even in rural areas of China, meaning residents do not need to worry about this factor.

It can be seen from Table 6 that $47.8 \%$ of the urban residents buy or rent farmhouse for the purpose of "residence after retirement, " which also confirms that the retirement factor has a large marginal benefit. The purpose of spending holidays ranked second, accounting for $28.3 \%$ of responses. The total proportion of homes used as residences after retirement and holiday is $76.1 \%$. It is fundamental that these people choose to buy or rent a rural farmhouse in pursuit of a quality environment in rural areas. 
Table 6. The main purpose of buying or renting a farmhouse.

\begin{tabular}{ccccc}
\hline & Daily Living & Holiday & $\begin{array}{c}\text { Residence after } \\
\text { Retirement }\end{array}$ & Others \\
\hline Sample Size & 26 & 32 & 54 & 1 \\
The percentage & $23.0 \%$ & $28.3 \%$ & $47.8 \%$ & $0.9 \%$ \\
\hline
\end{tabular}

It can be seen from Table 7 that the main reasons why most urban residents were unwilling to buy or rent a house are transportation problems, shopping not being convenient, and imperfect medical services. These reasons can be summarized as incomplete infrastructure and improvement of public services. Therefore, in the establishment of the VFM, it is necessary to improve rural infrastructure and public service levels.

Table 7. Reasons for unwillingness to sell a rural property.

\begin{tabular}{cccc}
\hline & Ranked First & Ranked Second & Ranked Third \\
\hline Economic conditions are not favorable & 8 & 0 & 1 \\
Legal restrictions & 5 & 5 & 1 \\
Transportation problems & 12 & 8 & 3 \\
Shopping is not convenient & 7 & 15 & 4 \\
Poor educational conditions & 4 & 1 & 7 \\
Imperfect medical services & 10 & 14 & 3 \\
Law and order is not good in that area & 2 & 1 & 3 \\
Dirty and disordered villages & 0 & 2 & 0 \\
Being from the countryside themselves & 9 & 4 & 1 \\
Other factors & 2 & 0 & 3 \\
\hline
\end{tabular}

\subsection{Affecting Factors}

\subsubsection{Factors Affecting House Owners' Willingness}

The Stereotype logistic regression results illustrate the relationship between the house owners' willingness and the affecting factors (see Table 8).

Among the explanatory variables, some variables show statistically significant relationships with the house owners' willingness to sell or rent out their homes. These variables include (1) age: this is a dummy variable with age 1 for ages 18-35 ( $p=0.02)$, age 2 for ages 36-45 $(p=0.01)$, and age 3 for ages 46-55 ( $p=0.01)$; (2) annual family income: The family annual income factor includes household annual income 2, which means that the annual household income is 10,000-30,000 yuan $(p=0.06)$, family annual income 3 means that the annual household income is 30,000-50,000 yuan $(p=0.07)$; (3) distance to main road ( $p=0.001)$ and (4) Status of vacant houses $(p=0.08)$.

"Age 1 " is significant on $p<0.05$. Age 2 and age 3 are both significant at the 0.01 level and are positively correlated with a willingness to sell rural property. At the same time, the willingness of young and middle-aged farmers aged 18-45 to sell or rent their vacant properties is stronger than that of middle-aged and elderly farmers aged 46-55 (the coefficients of age 1 and age 2 are greater than for age 3). This is very reasonable because, in China, young farmers aged 18-45 are often working or studying abroad, and after years of working, they have a certain amount of economic savings. Their economic savings can help them to purchase real estate in at least township level towns, so this group of farmers is very willing to sell or rent their vacant houses. However, middle-aged and elderly farmers aged 46-55 prefer the good environment of the countryside and consider it to be convenient if they can grow agricultural products for their own consumption. Therefore, the older the farmers are, the less willing they are to sell. 
Table 8. The estimation results of house owners' willingness to sell their properties.

\begin{tabular}{|c|c|c|c|c|c|}
\hline Variables & Coef. & Robust Std. Err. & $p>|z|$ & \multicolumn{2}{|c|}{ [95\% Conf Interval] } \\
\hline Age1 ** & 1.81 & 0.76 & 0.02 & 0.32 & 3.29 \\
\hline Age2 *** & 1.54 & 0.58 & 0.01 & 0.41 & 2.68 \\
\hline Age3 $* * *$ & 1.26 & 0.49 & 0.01 & 0.29 & 2.23 \\
\hline Age4 & 0.72 & 0.49 & 0.14 & -0.24 & 1.69 \\
\hline Marriage status & 0.42 & 0.33 & 0.21 & -0.24 & 1.07 \\
\hline Farmer & -0.61 & 0.64 & 0.34 & -1.87 & 0.64 \\
\hline Worker & -0.78 & 0.62 & 0.21 & -2.00 & 0.45 \\
\hline Businessman & 1.15 & 0.80 & 0.15 & -0.42 & 2.73 \\
\hline Annual family income1 & 1.13 & 1.07 & 0.29 & -0.97 & 3.24 \\
\hline Annual family income2 $*$ & 2.04 & 1.07 & 0.06 & -0.06 & 4.14 \\
\hline Annual family income3 * & 1.93 & 1.06 & 0.07 & -0.16 & 4.01 \\
\hline Annual family income4 & 0.44 & 1.04 & 0.67 & -1.59 & 2.47 \\
\hline Family size & -0.01 & 0.12 & 0.96 & -0.24 & 0.22 \\
\hline Number of labors & 0.13 & 0.21 & 0.56 & -0.29 & 0.55 \\
\hline Number of houses already owned & -0.46 & 0.36 & 0.21 & -1.17 & 0.25 \\
\hline House area & 0.01 & 0.00 & 0.12 & 0.00 & 0.01 \\
\hline Distance to towns & 0.08 & 0.05 & 0.15 & -0.03 & 0.18 \\
\hline Distance to main road ${ }^{* * *}$ & 0.00 & 0.00 & 0.01 & 0.00 & 0.00 \\
\hline House structure & -0.24 & 0.22 & 0.28 & -0.67 & 0.19 \\
\hline Status of vacant houses * & -0.27 & 0.15 & 0.08 & -0.57 & 0.03 \\
\hline Transactions in the villages & 0.04 & 0.25 & 0.87 & -0.44 & 0.52 \\
\hline $\begin{array}{l}\text { Knowledge about laws and } \\
\text { regulations }\end{array}$ & -0.07 & 0.12 & 0.59 & -0.30 & 0.17 \\
\hline $\begin{array}{l}\text { Attitudes on the current } \\
\text { regulations }\end{array}$ & 0.00 & 0.02 & 0.91 & -0.03 & 0.03 \\
\hline /phi1_1 & 1.00 & (constrained) & & & \\
\hline /phi1_2 & -0.32 & 0.26 & 0.23 & -0.84 & 0.20 \\
\hline /phi1_3 & 0.00 & (base outcome) & & & \\
\hline /theta1 & 0.68 & 1.94 & 0.73 & -3.13 & 4.48 \\
\hline /theta2 & -2.26 & 0.96 & 0.02 & -4.14 & -0.38 \\
\hline /theta3 & 0.00 & (base outcome) & & & \\
\hline
\end{tabular}

Note: ${ }^{*},{ }^{* *},{ }^{* * *}$ respectively represent the significance under $10 \%, 5 \%, 1 \%$ level.

Both the "Annual family income 2" and "Annual family income 3" are significant at the 0.1 level and are positively correlated with willingness. This shows that farmers whose annual household income is between 10,000 and 50,000 are more willing to sell or rent their vacant farmhouses. Among them, the coefficient of annual household income of 10,000-30,000 yuan is larger than for other farmers, indicating that they have a stronger willingness to sell. Most of these farmers are migrant workers, and their economic situation is not optimistic. They hope to improve their current economic situation by selling their vacant farmhouses.

"Distance to the main road" is also very significant $(p=0.01)$ and negatively correlated with willingness, which means that the house owners whose houses are farther to the main road are less likely to sell or rent out their vacant houses. "Distance to town" is not significant because the rapid development of current traffic has greatly shortened the time and space between urban and rural areas. Close to the highway means close to the city, so this factor has less influence on the willingness of house owners to sell.

"Status of vacant houses" is significant at the 0.05 level and negatively correlated with the willingness, which means that farmers with completely vacant houses are unlikely to be willing to sell or rent their houses, while farmers who own damaged houses are more willing to sell or rent their houses. This is because houses that are completely vacant but not damaged are usually better maintained, and the farmers who own them usually experience better economic conditions. 
The purpose of building these houses is mostly for accommodation when they return to the countryside for traditional Chinese festivals.

It can be seen from Table 9 that farmers' willingness to sell has a significant negative correlation with age, which also confirms the previous view. The older the farmers, the lower their willingness to participate in the market.

Table 9. Marginal effects of main affecting factors for house owners.

\begin{tabular}{|c|c|c|c|c|c|c|}
\hline & & $d y / d x$ & Std. Err. & $p>\mathbf{z}$ & {$[95 \% \mathrm{C}$} & terval] \\
\hline & & & & & & \\
\hline _predict & 1 & 0.07 & 0.02 & 0.00 & 0.02 & 0.11 \\
\hline & 2 & -0.02 & 0.02 & 0.17 & -0.06 & 0.01 \\
\hline & 3 & -0.04 & 0.02 & 0.02 & -0.08 & -0.01 \\
\hline Farmer & & & & & & \\
\hline _predict & 1 & 0.12 & 0.08 & 0.14 & -0.04 & 0.29 \\
\hline & 2 & -0.04 & 0.03 & 0.12 & -0.10 & 0.01 \\
\hline & 3 & -0.08 & 0.07 & 0.25 & -0.22 & 0.06 \\
\hline Businessı & & & & & & \\
\hline _predict & 1 & -0.15 & 0.12 & 0.20 & -0.38 & 0.08 \\
\hline & 2 & 0.05 & 0.06 & 0.41 & -0.07 & 0.18 \\
\hline & 3 & 0.10 & 0.06 & 0.12 & -0.03 & 0.22 \\
\hline $\begin{array}{l}\text { Number } \\
\text { already o }\end{array}$ & & & & & & \\
\hline _predict & 1 & 0.08 & 0.05 & 0.08 & -0.01 & 0.17 \\
\hline & 2 & -0.03 & 0.02 & 0.21 & -0.07 & 0.02 \\
\hline & 3 & -0.05 & 0.04 & 0.14 & -0.12 & 0.02 \\
\hline House ar & & & & & & \\
\hline _predict & 1 & 0.00 & 0.00 & 0.02 & 0.00 & 0.00 \\
\hline & 2 & 0.00 & 0.00 & 0.12 & 0.00 & 0.00 \\
\hline & 3 & 0.00 & 0.00 & 0.08 & 0.00 & 0.00 \\
\hline $\begin{array}{l}\text { Distance } \\
\text { road }\end{array}$ & & & & & & \\
\hline _predict & 1 & 0.16 & 0.05 & 0.00 & 0.06 & 0.25 \\
\hline & 2 & -0.05 & 0.04 & 0.15 & -0.13 & 0.02 \\
\hline & 3 & -0.10 & 0.04 & 0.01 & -0.18 & -0.02 \\
\hline $\begin{array}{l}\text { Status of } \\
\text { houses }\end{array}$ & & & & & & \\
\hline _predict & 1 & 0.05 & 0.02 & 0.03 & 0.00 & 0.09 \\
\hline & 2 & -0.02 & 0.01 & 0.17 & -0.04 & 0.01 \\
\hline & 3 & -0.03 & 0.02 & 0.08 & -0.06 & 0.00 \\
\hline
\end{tabular}

\subsubsection{Factors Affecting Urban Residents' Willingness}

The Stereotype logistic regression results illustrate the relationship between the urban residents' willingness and the affecting factors (see Table 10).

The most significant explanatory variables related to the urban residents' willingness were (1) business owners $(p=0.01)$, (2) family size $(p=0.08)$, (3) house area: " house area 1" represents a house area less than 100 square meters $(p=0.08)$, and house area 2 represents a house area between $100-200$ square meters $(p=0.03)$; (4) attitudes toward the prospect of VFM $(p=0.05)$.

The influencing factor of the "Business owners " is significant at the $p=0.01$ level and is positively correlated with willingness. This shows that urban residents who are business owners in all occupations are more willing to buy or lease vacant farmhouses than other urban residents because the bosses of their companies are usually more economically ambitious and pay more attention to a quiet environment, fresh air, and food safety. 
Table 10. The estimation results of urban residents' willingness.

\begin{tabular}{lccccc}
\hline \multicolumn{1}{c}{ Variables } & Coef. & Std. Err. & $\boldsymbol{p}>\mathbf{| z |}$ & [95\% Conf. Interval] \\
\hline Age1 & 0.81 & 1.08 & 0.45 & -1.31 & 2.94 \\
Age2 & 0.81 & 1.00 & 0.42 & -1.14 & 2.76 \\
Age3 & 0.38 & 1.02 & 0.71 & -1.62 & 2.38 \\
Age4 & 0.92 & 0.94 & 0.33 & -0.92 & 2.76 \\
Marriage status & 0.52 & 0.33 & 0.11 & -0.12 & 1.16 \\
Civil servants & 1.02 & 0.66 & 0.12 & -0.27 & 2.31 \\
Company staff & 0.60 & 0.62 & 0.33 & -0.61 & 1.81 \\
Business owners *** & 1.45 & 0.57 & 0.01 & 0.34 & 2.56 \\
Retired & 1.16 & 1.27 & 0.36 & -1.33 & 3.64 \\
Housewife & 0.84 & 0.88 & 0.34 & -0.88 & 2.56 \\
Family size * & 0.28 & 0.16 & 0.08 & -0.03 & 0.59 \\
Number of houses & -0.07 & 0.43 & 0.87 & -0.92 & 0.77 \\
Family income per month1 & 0.52 & 0.98 & 0.60 & -1.40 & 2.44 \\
Family income per month2 & -0.05 & 0.75 & 0.94 & -1.52 & 1.41 \\
Family income per month3 & -0.44 & 0.87 & 0.61 & -2.14 & 1.26 \\
Family income pe rmonth4 & 1.53 & 0.99 & 0.12 & -0.41 & 3.47 \\
House area1 * & 1.64 & 0.94 & 0.08 & -0.20 & 3.48 \\
House area2** & 1.75 & 0.81 & 0.03 & 0.16 & 3.34 \\
Already own farm houses or not & -0.05 & 0.32 & 0.87 & -0.67 & 0.57 \\
Attitude toward the prospect of VFM ** & -0.73 & 0.37 & 0.05 & -1.45 & 0.00 \\
\hline /phi1_1 & 1.00 & (constrained) & & & \\
/phi1_2 & 0.67 & 0.42 & 0.11 & -0.14 & 1.49 \\
/phi1_3 & 0.00 & $($ base & & & \\
\hline /theta1 & 2.63 & 1.94 & 0.18 & -1.17 & 6.43 \\
/theta2 & 2.24 & 1.70 & 0.19 & -1.09 & 5.56 \\
/theta3 & 0.00 & $($ base & & & \\
\hline & outcome) & & & \\
\hline
\end{tabular}

Note: ${ }^{*}, * *$ and ${ }^{* * *}$ respectively represent the significance levels under $10 \%, 5 \%$, and $1 \%$ levels.

The factor of "House area 1" is significant at the level of $p=0.1$, the factor of "House area 2" is significant at the level of $p=0.05$, and both are positively correlated with willingness, and the coefficient of house area 2 is greater than that of house area 1 . This shows that urban residents have a residential area of 100-200 square meters, and they are more willing to rent or purchase vacant rural houses.

"Family size" is significant because if a large family is more likely that the family to need one more house or a larger house than a smaller family. Also a large family is more likely to include some old people, and they may need a farmhouse for their retirement. As the answer to the question of the main purpose of buying or renting a farmhouse, a high percentage of these big families chose "retirement."

The factor "Attitude toward the prospect of VFM" was significantly negatively correlated with willingness at the $p=0.05$ level. This means those urban residents who are pessimistic about the prospects of VFM have a stronger willingness to participate in this market. This seems counterintuitive, but we found that most urban residents were pessimistic about the prospects of the VFM, but they still had a strong willingness to participate. The main reason for this is that urban residents take into account the current legal restrictions on rural real estate transactions, which has led to their pessimistic view of the market. If the VFM market were to be established, all those institutional barriers would have been eliminated. Also, if most urban residents were not buying or renting rural real estate to make a profit, this would necessarily not affect their willingness to participate in the market.

The $p$-value could not show the effect size-which is to some extent more important than the statistical significance [62]. Thus, we further quantified the marginal effects of the affecting factors. The marginal effects of factors that are significant under stereotype logistic estimation and another factor-"retired, "which was not significant under a stereotype logistic model but had a big marginal effect are listed below in Table 11. For "Retired, " the marginal effects were big and significant for the 
unwilling group and were negatively correlated with willingness. This means that the closer urban residents are to retirement age, the stronger their willingness to buy vacant farmhouse. This is likely to be because after they retire, they will not need to work in the city but would rather seek a good life in a natural environment. Also staffs of administrative units tend to be willing to rent or buy vacant farmhouses. This because this group of people often live a relatively comfortable life; they have the time and capability as well as having enough knowledge to care much about having a better living environment.

Table 11. Marginal effects of the main affecting factors for urban residents.

\begin{tabular}{|c|c|c|c|c|c|c|}
\hline \multicolumn{2}{|c|}{ 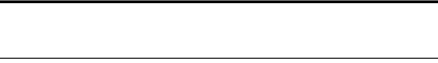 } & \multirow[t]{2}{*}{$\mathrm{dy} / \mathrm{dx}$} & \multirow[t]{2}{*}{ Std. Err. } & \multirow[t]{2}{*}{$p>\mathrm{z}$} & \multicolumn{2}{|c|}{ [95\% Conf. Interval] } \\
\hline \multicolumn{4}{|c|}{ Marriage status } & & & \\
\hline \multirow[t]{3}{*}{ _predict } & 1 & -0.04 & 0.03 & 0.12 & -0.10 & 0.01 \\
\hline & 2 & -0.04 & 0.03 & 0.24 & -0.10 & 0.03 \\
\hline & 3 & 0.08 & 0.03 & 0.11 & -0.02 & -0.18 \\
\hline \multicolumn{7}{|c|}{ Civil servants } \\
\hline \multirow[t]{3}{*}{ _predict } & 1 & -0.09 & 0.05 & 0.06 & -0.19 & 0.01 \\
\hline & 2 & -0.08 & 0.08 & 0.26 & -0.23 & 0.06 \\
\hline & 3 & 0.18 & 0.11 & 0.10 & -0.03 & 0.39 \\
\hline \multicolumn{7}{|c|}{ Business owners } \\
\hline \multirow[t]{3}{*}{ _predict } & 1 & -0.13 & 0.05 & 0.01 & -0.23 & -0.03 \\
\hline & 2 & -0.12 & 0.08 & 0.17 & -0.28 & 0.05 \\
\hline & 3 & 0.24 & 0.10 & 0.01 & 0.05 & 0.44 \\
\hline \multicolumn{7}{|l|}{ Retired } \\
\hline \multirow[t]{3}{*}{ _predict } & 1 & -0.11 & 0.07 & 0.10 & -0.25 & 0.02 \\
\hline & 2 & -0.10 & 0.11 & 0.34 & -0.31 & 0.11 \\
\hline & 3 & 0.22 & 0.16 & 0.17 & -0.09 & 0.53 \\
\hline \multicolumn{7}{|c|}{ Family size } \\
\hline \multirow[t]{3}{*}{ _predict } & 1 & -0.03 & 0.02 & 0.10 & -0.06 & 0.00 \\
\hline & 2 & -0.03 & 0.01 & 0.06 & -0.05 & 0.00 \\
\hline & 3 & 0.05 & 0.02 & 0.01 & 0.01 & 0.09 \\
\hline \multicolumn{7}{|c|}{$\begin{array}{l}\text { Attitude toward the } \\
\text { prospect of VFM }\end{array}$} \\
\hline \multirow[t]{3}{*}{ _predict } & 1 & 0.07 & 0.04 & 0.06 & 0.00 & 0.14 \\
\hline & 2 & 0.06 & 0.02 & 0.01 & 0.01 & 0.11 \\
\hline & 3 & -0.13 & 0.03 & 0.00 & -0.19 & -0.07 \\
\hline
\end{tabular}

Note: 1, 2, 3 respectively represent the outcome based on "unwilling, " not sure, " and "willing.".

\subsection{Results Discussion}

As we interpreted above, the estimation results agree with our observations on the ground and seem plausible. We also compared our study with the previous researches in the literature. We found the results were more or less confirmed by previous analyses. In our findings, farmers' willingness to sell rural houses were strongly affected by farmers' age and the condition of the houses. This was supported by a previous study in China by Hare [63]. We further demonstrated that farmers' willingness to sell dwindles as they age. This finding is consistent with Song's research results [64]. Moreover, our study found that the distance between the house and main roads is negatively related to farmers' willingness to participate in the market. This result is consistent with Cloke's view: due to the proximity to the market, farmers near the city have more opportunities and a greater willingness to rent out houses or sell them to others [65]. In addition, this study found that farmers' willingness to sell houses is generally higher in more developed cities. This finding is consistent with Van Dijk's research, in which he showed that the economic environment has an impact on farmers' decisions on whether to buy and sell lands based on the data from Poland, Hungary, and other countries [66].

The empirical results also show that the willingness of urban residents to buy houses is related to their social status. For example, business owners are more willing to buy rural houses due to their 
economic status and flexible working times. This finding is not surprising and has been confirmed by many studies. For example, Turner showed that residents' willingness to buy extra real estate is strongly influenced by their socioeconomic statuses. The residents with weaker socioeconomic statuses are less willing to buy houses, and vice versa [67]. Also, the natural environmental conditions of homesteads will be the main factors considered by urban residents when purchasing homesteads, which also supports Tan's research [68].

\section{Conclusions and Policy Implications}

\subsection{Conclusions}

Massive and rapid urbanization leads to a high prevalence of vacant farmhouses across China. Due to institutional barriers and land tenure settings, these vacant houses cannot be easily sold or rented. The Chinese governments started to relax the rural land market by piloting the separation of three rights of rural lands, including for the homestead. Under this context, this research tried to answer whether there are a potential supply and demand for the establishment of the vacant house market and what are influencing factors for the willingness of house owners and potential buyers, i.e., urban residents. Hence, we used stereotype logical regression to empirically estimate the influencing factors on house owners and urban residents' willingness to participate in the VFM based on 571 sample data points collected from six cities in Sichuan Province, China.

The results can be summarized as follows:

(1) There is a strong willingness of both house owners and urban residents to participate in the VFM. More than $60 \%$ of rural house owners and urban residents, particularly those in the economically developed and moderately developed areas, are willing to participate in the potential VFM. The matching analysis showed a good match in the demand and supply in most regions, such as Leshan, Nanchong, Suining, Dazhou, and Yibin. Thus, we showed a precondition for establishing VFM, that is, the matching supply-demand in the study region.

(2) Concerning the influencing factors of the willingness, we showed that the main influencing factors of house owners' willingness to rent out or sell their houses include sociodemographic characteristics of farmers (e.g., age, household income) and characteristics of the vacant houses (e.g., distance to the main roads, the status of vacant houses). On the other side, the major factors that affect the willingness of urban residents to rent in or purchase vacant rural houses, in the order of importance, are occupation, forecasts of the market, family size, house area, and family income per month.

Moreover, the most important reason for urban residents to purchase vacant farmhouses is to seek a good living environment in the countryside. Secondly, the urban residents value purchased vacant farmhouses that possess good transportation conditions, access to tap water, and good Internet and mobile telephone signals. Finally, for those urban residents who are not willing to participate in the marketization of vacant farmhouses, the main factors affecting their willingness are the infrastructure and public service levels for rural vacant farmhouses.

As such, this paper fills a research void in the literature by analyzing the feasibility of establishing the potential vacant farmhouse market and quantifying the factors behind the willingness of market agents, both the suppliers (i.e., farmers) and demanders (i.e., urban residents). We hope this research will stimulate more related research in studying the VFM-an emerging topic in the sustainable urbanization and harmonious development of urban and rural areas. Thus, this research also addresses a highly timing issue and has practical significance in improving the utilization efficiency of idle homesteads in rural areas under the backdrop of the rural land reforms, namely, the "Separation of three rights" reform. 


\subsection{Policy Implications}

As said, this research has profound policy implications besides its scientific contribution. Based on the research results, we can draw a few policy recommendations:

(1) Governments should continue deepening the institutional reforms on the rural land tenure settings, especially the separation of three rights, which allows the transaction of farmhouses' use rights without the transfer of the land/homestead ownership. Farmland reforms have proved to be successful, and cropland transfer has witnessed a substantial increase all over China. The homestead reforms, despite having only been started recently, have great potential in increasing the utilization rate of idle farmhouses and farmers' property income. This is critical to the goal of rural revitalization. The institutional reforms need to go beyond the homestead and rural land reform. The hukou reform and rural social security system are key to facilitating sustainable urbanization and ensuring farmers' welfare, including migrants in rural areas and cities. With job security and social security, farmers are more likely to give up their homesteads-which, to a large degree, play an important social security role.

(2) VFM should be firstly experimented with and established in pilot regions where there are enough supply and demand and good transportation fractures, for example, in our case, a city with a high degree of matching between the willingness of urban residents and house owners: Leshan. When VFM is successful in the pilot region, other regions can learn from the experiences and later establish VFM as well.

(3) The government should play an active role in establishing VFM by regulating the market and establishing rural houses exchange platforms. According to the survey, most farmers hope that the government will guide the establishment of VFM. At present, the government plays an irreplaceable role in promoting the rational distribution of resources and improving the overall resource allocation capacity of the society. The government should strengthen macroeconomic regulation and control, integrate and utilize the existing vacant housing in rural areas, give full play to the government's guiding role, improve the infrastructure conditions in rural areas, and promote the marketization of vacant rural housing.

(4) Rural infrastructure improvement and maintenance are important factors in ensuring VFM. Together with enterprises, governments need to further improve transportation (e.g., highways, and light rail to rural regions) and drinking water facilities, as these two factors are the most concerned factors for urban residents when considering to live in rural areas. Furthermore, other services like hospitals and shopping centers are also important.

(5) Green mountains and clean water initiative promoted by the Central government to improve the rural natural environment will be the main enabling factors for VFM, as most urban residents choose to buy property in the countryside with the hope of enjoying a good natural environment. Therefore, the government should vigorously develop a rural ecological civilization and maintain the countryside's natural environment.

\subsection{Limitations and Future Directions}

As one of the pioneering studies in VFM, we concede that there are some limitations, and many aspects can be improved. For example, as there is no functioning VFM, the willingness we elicited from agents is merely the stated willingness-which may not be consistent with what they will do in reality. The data sample size is sufficient for the analysis, but it can be larger to catch more variations in the study region. Further research is needed to assess whether these research results apply to other provinces with different economic development levels (e.g., coastal regions) and topographical areas (e.g., the plain areas). In addition, this research focuses on the willingness of urban residents and farmers to participate in VFM. The establishment of VFM may involve many other factors, notably price, and other details-which we largely ignored in this research. Since establishing the vacant homestead market is an important part of ensuring the successful circulation of homesteads, future 
research should be conducted. We hope this research will stimulate further valuable research on the rural housing market in China and other emerging countries.

Author Contributions: Conceptualization, Q.Y.; Data curation, H.T., and J.H.; Formal analysis, J.H.; Funding acquisition, Q.Y.; Investigation, Q.Y., Z.S., and H.T.; Methodology, J.H., and D.X.; Resources, Z.S.; Software, J.H.; Supervision, Q.Y.; Writing—original draft, Q.Y.; Writing—review \& editing, J.H., Z.S., G.N.-A. All authors have read and agreed to the published version of the manuscript.

Funding: This research was funded by the scientific research project of Sichuan provincial humanities and social science key research base of Sichuan Center for Rural Development Research (CR1605) and Humanities and Social Sciences Project of the Ministry of Education (17YJA630124).

Acknowledgments: This work was supported by the scientific research project of Sichuan provincial humanities and social science key research base of Sichuan Center for Rural Development Research (CR1605) and Humanities and Social Sciences Project of the Ministry of Education (17YJA630124). We also thank the Leibniz Institute of Agricultural Development in Transition Economies (IAMO) for its support and help with this research. The authors also extend great gratitude to the editors and anonymous reviewersfor their helpful review and critical comments.

Conflicts of Interest: The authors declare no conflict of interest.

\section{Appendix A}

Table A1. Variable description and statistical features of house owners.

\begin{tabular}{|c|c|c|c|c|c|}
\hline Variable Name & Variable Definition & Min & Max & Mean & Std. Dev. \\
\hline \multicolumn{6}{|l|}{ Dependent variable } \\
\hline $\begin{array}{l}\text { Willingness to sell or rent } \\
\text { house }(\mathrm{Y})\end{array}$ & $\begin{array}{l}\text { Unwilling }=1, \text { not sure }=2, \\
\text { willing }=3\end{array}$ & 1 & 3 & 2.40 & 0.84 \\
\hline \multicolumn{6}{|l|}{$\begin{array}{l}\text { Independent variable } \\
\text { 1. Individual characteristic variables }\end{array}$} \\
\hline Age $\left(X_{1}\right)$ & $\begin{array}{c}18-35=1,36-45=2,46-55=3 \\
56-60=4,>60=5\end{array}$ & 1 & 5 & 2.93 & 1.32 \\
\hline Marital status $\left(X_{2}\right)$ & Single $=0$, Married $=1$ & 0 & 1 & 0.90 & 0.29 \\
\hline \multicolumn{6}{|l|}{ Occupation $\left(X_{3}\right)$} \\
\hline Farmer $\left(\mathrm{X}_{31}\right)$ & $\mathrm{Yes}=1, \mathrm{No}=0$ & 0 & 1 & 0.36 & 0.48 \\
\hline Worker $\left(X_{32}\right)$ & Yes $=1, \mathrm{No}=0$ & 0 & 1 & 0.33 & 0.47 \\
\hline Businessman $\left(X_{33}\right)$ & Yes $=1, \mathrm{No}=0$ & 0 & 1 & 0.15 & 0.36 \\
\hline Other $\left(X_{34}\right)$ & Yes $=1$, No $=0$ & 0 & 1 & 0.15 & 0.36 \\
\hline \multicolumn{6}{|l|}{ 2. Household characteristics } \\
\hline Annual family income $\left(X_{4}\right)$ & $\begin{array}{c}<10,000=1 ; 10,000-30,000= \\
2 ; 30,000-50,000=3 \\
50,000-100,000=4 \\
>100,000=5\end{array}$ & 1 & 5 & 2.31 & 1.00 \\
\hline Family size $\left(X_{5}\right)$ & Family size & 1 & 14 & 4.62 & 1.73 \\
\hline Number of labor $\left(\mathrm{X}_{6}\right)$ & Number of family labor & 0 & 8 & 2.57 & 1.15 \\
\hline $\begin{array}{l}\text { Number of houses already } \\
\text { owned }\left(X_{7}\right)\end{array}$ & $\begin{array}{l}0=1 ; 1=2 ; 2=3 \\
\text { more than } 2=4\end{array}$ & 1 & 4 & 2.39 & 0.55 \\
\hline \multicolumn{6}{|l|}{ 3.House characteristics } \\
\hline House area $\left(X_{8}\right)$ & Area of house $\left(\mathrm{M}^{2}\right)$ & 18 & 400 & 153.55 & 54.66 \\
\hline Distance to town $\left(X_{9}\right)$ & $\begin{array}{l}\text { Distance from the house to the } \\
\text { town }(\mathrm{Km})\end{array}$ & 1 & 18 & 3.95 & 3.38 \\
\hline Distance to highway $\left(\mathrm{X}_{10}\right)$ & $\begin{array}{c}\text { Distance from the house to the } \\
\text { highway }(\mathrm{m})\end{array}$ & 0 & 5000 & 205.83 & 486.37 \\
\hline $\begin{array}{l}\text { Condition and structure of the } \\
\text { vacant farmhouse }\left(X_{11}\right)\end{array}$ & $\begin{array}{l}\text { Bad }(\text { earth and wood })=1, \\
\text { normal }(\text { Brick and wood })=2, \\
\text { good }(\text { Brick and concrete })=3\end{array}$ & 1 & 3 & 2.36 & 0.81 \\
\hline Status of vacant houses $\left(\mathrm{X}_{12}\right)$ & $\begin{array}{l}\text { Damaged }=0 ; \text { Occasionally } \\
\text { live }=1 ; \text { totally vacant }=2\end{array}$ & 0 & 2 & 1.44 & 0.66 \\
\hline \multicolumn{6}{|l|}{ 4.Relative knowledge } \\
\hline $\begin{array}{l}\text { Knowledge about farmhouse } \\
\text { transactions in your village }\left(X_{13}\right)\end{array}$ & $\mathrm{No}=1 ;$ A little $=2, \mathrm{Much}=3$ & 1 & 3 & 1.62 & 0.49 \\
\hline $\begin{array}{l}\text { Knowledge about law and } \\
\text { regulation of farmhouse }\left(\mathrm{X}_{14}\right)\end{array}$ & No $=1$, A little $=2$, Much $=3$ & 1 & 3 & 1.62 & 0.51 \\
\hline $\begin{array}{l}\text { Do you think the current law and } \\
\text { regulation is reasonable or } \\
\text { not }\left(X_{15}\right)\end{array}$ & $\begin{array}{l}\text { Unreasonable }=1, \text { not sure }=2, \\
\text { reasonable }=3\end{array}$ & 1 & 3 & 1.57 & 0.81 \\
\hline
\end{tabular}


Table A2. Variable description and statistical features of urban residents.

\begin{tabular}{|c|c|c|c|c|c|}
\hline Variable Name & Variable Definition & Min & Max & Mean & Std. Dev. \\
\hline \multicolumn{6}{|l|}{ Dependent variable } \\
\hline Willingness (Y) & $\begin{array}{l}\text { Unwilling }=1 ; \text { not } \\
\text { sure }=2 ; \text { willing }=3\end{array}$ & 1 & 3 & 2.16 & 0.77 \\
\hline \multicolumn{6}{|l|}{$\begin{array}{l}\text { Independent variables } \\
\text { 1.Individual characteristic } \\
\text { variables }\end{array}$} \\
\hline Age $\left(X_{1}\right)$ & $\begin{aligned} 18-35 & =1 ; 36-45=2 \\
46-55 & =3 ; 56-60=4 \\
& >60=5\end{aligned}$ & 1 & 5 & 2.39 & 1.26 \\
\hline $\begin{array}{l}\text { Marriage status }\left(X_{2}\right) \\
\text { Occupation }\left(X_{3}\right)\end{array}$ & Single $=0 ;$ married $=1$ & 0 & 1 & 0.74 & 0.44 \\
\hline Civil servants $\left(\mathrm{X}_{31}\right)$ & Yes $=1, \mathrm{No}=0$ & 0 & 1 & 0.20 & 0.40 \\
\hline Company staff $\left(X_{32}\right)$ & Yes $=1, \mathrm{No}=0$ & 0 & 1 & 0.17 & 0.38 \\
\hline Business owners $\left(\mathrm{X}_{33}\right)$ & Yes $=1, \mathrm{No}=0$ & 0 & 1 & 0.29 & 0.45 \\
\hline Retired $\left(X_{34}\right)$ & Yes $=1$, No $=0$ & 0 & 1 & 0.06 & 0.24 \\
\hline Housewife $\left(X_{35}\right)$ & Yes $=1, \mathrm{No}=0$ & 0 & 1 & 0.12 & 0.32 \\
\hline $\begin{array}{l}\text { Others }\left(\mathrm{X}_{36}\right) \\
\text { 2.Household characteristics }\end{array}$ & Yes $=1, \mathrm{No}=0$ & 0 & 1 & 0.16 & 0.37 \\
\hline Family size $\left(X_{4}\right)$ & $\begin{array}{l}\text { Number of people } \\
\text { in the family }\end{array}$ & 1 & 10 & 3.86 & 1.35 \\
\hline Number of houses $\left(X_{5}\right)$ & $\begin{array}{c}0=1 ; 1=2 ; 2=3 ; \text { more } \\
\quad \operatorname{than} 2=4 \\
<10,000=1\end{array}$ & 1 & 4 & 2.40 & 0.75 \\
\hline $\begin{array}{l}\text { Family income per } \\
\text { month }\left(X_{6}\right)\end{array}$ & $\begin{array}{c}10,000-30,000=2 \\
30,000-50,000=3 \\
50,000-100,000=4 \\
\quad>100,000=5\end{array}$ & 1 & 5 & 2.51 & 0.90 \\
\hline \multicolumn{6}{|l|}{ 3.House characteristics } \\
\hline House area $\left(X_{7}\right)$ & $\begin{array}{c}<100 \mathrm{~m}^{2}=1,100-200 \mathrm{~m}^{2} \\
\quad=2,>200 \mathrm{~m}^{2}=3\end{array}$ & 1 & 3 & 1.68 & 0.63 \\
\hline $\begin{array}{l}\text { Already own farmhouses } \\
\text { or not }\left(\mathrm{X}_{8}\right) \\
\text { 4.Relative knowledge }\end{array}$ & No $=0$, Yes $=1$ & 0 & 1 & 0.21 & 0.43 \\
\hline $\begin{array}{l}\text { Attitude toward the } \\
\text { prospect of vacant } \\
\text { farmhouse market }\left(X_{9}\right)\end{array}$ & $\begin{array}{l}\text { Not optimistic }=1 \\
\text { neutral }=2 \\
\text { optimistic }=3\end{array}$ & 1 & 3 & 2.02 & 0.54 \\
\hline
\end{tabular}

Table A3. Aspects that need improvement.

\begin{tabular}{cccccc}
\hline & $\begin{array}{c}\text { Perfecting the } \\
\text { Land Transfer }\end{array}$ & $\begin{array}{c}\text { The Housing } \\
\text { Free Sale }\end{array}$ & $\begin{array}{c}\text { Allow Rural } \\
\text { Real Estate } \\
\text { Development }\end{array}$ & $\begin{array}{c}\text { Allow the Rural } \\
\text { Land for } \\
\text { Non-Agricultural } \\
\text { Construction }\end{array}$ & Others \\
\hline $\begin{array}{c}\text { The number } \\
\text { of people }\end{array}$ & 83 & 111 & 74 & 22 & 5 \\
\hline
\end{tabular}

Note: Each option is multiple choices.

Table A4. Unwilling reason.

\begin{tabular}{ccccccc}
\hline & $\begin{array}{c}\text { Lived for } \\
\text { Many Years } \\
\text { with } \\
\text { Feelings }\end{array}$ & Self-Occupation & $\begin{array}{c}\text { House } \\
\text { Current Has } \\
\text { Use }\end{array}$ & $\begin{array}{c}\text { Wait-and-See } \\
\text { Market, } \\
\text { When Price } \\
\text { Rises, Sell It }\end{array}$ & $\begin{array}{c}\text { Plan to } \\
\text { Leave It to } \\
\text { Posterity }\end{array}$ & Others \\
\hline $\begin{array}{c}\text { The number } \\
\text { of people }\end{array}$ & 3 & 12 & 27 & 0 & 12 & 11 \\
\hline
\end{tabular}




\section{References}

1. Liu, Y.S. Introduction to land use and rural sustainability in China. Land Use Policy 2018, 74, 1-4. [CrossRef]

2. Liu, Y.S.; Liu, Y.; Chen, Y.F.; Long, H.L. The process and driving forces of rural hollowing in China under rapid urbanization. J. Geogr. Sci. 2010, 20, 876-888. [CrossRef]

3. Liu, Y.; Fang, F.; Li, Y. Key issues of land use in China and implications for policy making. Land Use Policy 2014, 40, 6-12. [CrossRef]

4. Bai, X.M.; Shi, P.J.; Liu, Y.S. Realizing china's urban dream. Nature 2014, 509, 158-160. [CrossRef] [PubMed]

5. Mohabir, N.; Jiang, Y.P.; Ma, R.F. Chinese floating migrants: Rural-urban migrant labourers' intentions to stay or return. Habitat Int. 2017, 82, 72-82. [CrossRef]

6. Cao, Z.; Zheng, X.Y.; Liu, Y.S.; Li, Y.R.; Chen, Y.F. Exploring the changing patterns of China's migration and its determinants using census data of 2000 and 2010. Habitat Int. 2018, 82, 72-82. [CrossRef]

7. Nedved, M.; Jansz, J. Waste water pollution control in the Australian mining industry. J. Clean. Prod. 2006, 14, 1118-1120. [CrossRef]

8. Ng, B.J.H.; Zhou, J.; Giannis, A.; Chang, V.W.C.; Wang, J.Y. Environmental life cycle assessment of different domestic wastewater streams: Policy effectiveness in a tropical urban environment. J. Environ. Manag. 2014, 140, 60-68. [CrossRef]

9. Lamb, H.H. Industrial smoke drift and weather. Q. J. R. Meteorol. Soc. 2007, 64, 639-643. [CrossRef]

10. Lai, L.; Huang, X.J.; Yang, H.; Chuai, X.W.; Zhang, M.; Zhong, T.Y.; Chen, Z.G.; Chen, Y.; Wang, X.; Thompson, J.R. Carbon emissions from land-use change and management in china between 1990 and 2010. Sci. Adv. 2016, 2, e1601063. [CrossRef]

11. Cai, W.; Liu, C.H.; Zhang, C.X.; Ma, M.D.; Rao, W.Z.; Li, W.Y.; He, K.; Gao, M.D. Developing the ecological compensation criterion of industrial solid waste based on emergy for sustainable development. Energy 2018, 157, 940-948. [CrossRef]

12. Liu, Y.S.; Li, Y.H. Revitalize the world's countryside. Nature 2017, 548, 275-277. [CrossRef] [PubMed]

13. Vlahov, D. Urban Health: Global Perspectives; Jossey-Bass: San Francisco, CA, USA, 2011.

14. Dieterlen, S.S. Immigrant Pastoral: Midwestern Landscapes and Mexican-American Neighborhoods; Routledge: Abingdon, UK, 2017. [CrossRef]

15. Szul, R. Surviving in a peripheral periphery case studies from eastern Poland. Eur. XXI 2006, 15, 135-144.

16. Maiti, S.; Agrawal, P.K. Environmental degradation in the context of growing urbanization: A focus on the metropolitan cities of India. J. Hum. Ecol. 2005, 17, 277-287. [CrossRef]

17. Hiltunen, M.J.; Pitknen, K.; Vepslinen, M.; Hall, C.M. Second home tourism in Finland: Current trends and eco-social impacts. In Second Home Tourism in Europe: Lifestyle Issues and Policy Responses; Routledge: Abingdon, UK, 2013; pp. 165-198.

18. National Bureau of Statistics of China (NBSC). China Statistical Yearbook 2014; China Statistics Press: Beijing, China, 2019.

19. Ministry of Housing and Urban-Rural Development of China (MLRC). China Urban-Rural Construction Statistical Yearbook 2014; China Statistics Press: Beijing, China, 2019.

20. Yang, R.; Liu, Y.S.; Chen, Y.F. Comprehensive measure and partition of rural hollowing in China. Geogr. Res. 2012, 31, 1697-1706. (In Chinese)

21. Wang, X.R.; Hui, E.C.M.; Choguill, C.; Jia, S.H. The new urbanization policy in China: Which way forward? Habitat International 2015, 47, 279-284. [CrossRef]

22. Wu, Q.Y.; Zhang, X.L.; Xu, Y.L.; Li, T. Dualities of semi-urbanization villages in social-spatial transition: A case study of zhoucun village in suburban nanjing, china. J. Rural Stud. 2016, 47, 657-664. [CrossRef]

23. Tao, R.; Xu, Z. Urbanization, rural land system and social security for migrants in China. J. Dev. Stud. 2007, 43, 1301-1320. [CrossRef]

24. Wu, Y.Z.; Mo, Z.B.; Peng, Y.; Skitmore, M. Market-driven land nationalization in china: A new system for the capitalization of rural homesteads. Land Use Policy 2017, 70, 559-569. [CrossRef]

25. Chen, R.S.; Ye, C.; Cai, Y.L.; Xing, X.S.; Chen, Q. The impact of rural out-migration on land use transition in china: Past, present and trend. Land Use Policy 2014, 40, 101-110. [CrossRef]

26. Huang, R.J.; Zhang, Y.L.; Bozzetti, C. High secondary aerosol contribution to particulate pollution during haze events in china. Nature 2014, 514, 218-222. [CrossRef] [PubMed] 
27. Zhang, X.Y.; Wang, Y.Q.; Niu, T.; Zhang, X.C.; Gong, S.L.; Zhang, Y.M.; Sun, J.Y. Atmospheric aerosol compositions in China: Spatial/temporal variability, chemical signature, regional haze distribution and comparisons with global aerosols. Atmos. Chem. Phys. 2012, 12, 779-799. [CrossRef]

28. Guo, S.; Hu, M.; Zamora, M.L.; Peng, J.F.; Zhang, R.Y. Elucidating severe urban haze formation in china. Proc. Natl. Acad. Sci. USA 2014, 111, 17373. [CrossRef] [PubMed]

29. Barth, J.R.; Lea, M.; Li, T. China's housing market: Is a bubble about to burst? SSRN Electron. J. 2012, 74-78. [CrossRef]

30. Lu, Y.L.; Song, S.; Wang, R.S.; Liu, Z.Y.; Meng, J.; Sweetman, A.J.; Jenkins, A.; Ferrier, R.C.; Li, H.; Luo, W.; et al. Impacts of soil and water pollution on food safety and health risks in china. Environ. Int. 2015, 77, 5-15. [CrossRef]

31. Zhai, F.Y.; Du, S.F.; Wang, Z.H.; Zhang, J.G.; Popkin, B.M. Dynamics of the chinese diet and the role of urbanicity, 1991-2011. Obes. Rev. 2014, 15, 16-26. [CrossRef]

32. Wang, F.; Wei, X.J.; Liu, J.; He, L.Y.; Gao, M.N. Impact of high-speed rail on population mobility and urbanisation: A case study on yangtze river delta urban agglomeration, China. Transp. Res. 2019, 127, 99-114. [CrossRef]

33. Chen, Z.G.; Wang, Q.; Huang, X.J. Can land market development suppress illegal land use in China? Habitat Int. 2015, 49, 403-412. [CrossRef]

34. Chen, H.C.; Zhao, L.M.; Zhao, Z.Y. Influencing factors of farmers' willingness to withdraw from rural homesteads: A survey in zhejiang, china. Land Use Policy 2017, 68, 524-530. [CrossRef]

35. Zou, Y.H.; Zhao, W.X.; Mason, R. Marketization of collective-owned rural land: A breakthrough in Shenzhen, China. Sustainability 2014, 6, 9114-9123. [CrossRef]

36. Kong, X.S.; Liu, Y.L.; Jiang, P.; Tian, Y.S.; Zou, Y.F. A novel framework for rural homestead land transfer under collective ownership in china. Land Use Policy 2018, 78, 138-146. [CrossRef]

37. Zhou, Y.; Li, X.H.; Liu, Y.S. Rural land system reforms in China: History, issues, measures and prospects. Land Use Policy 2020, 91, 104330. [CrossRef]

38. Gao, J.L.; Liu, Y.S.; Chen, J.L. China's initiatives towards rural land system reform. Land Use Policy 2020, 94, 104567. [CrossRef]

39. Wang, Y.P.; Murie, A. Commercial housing development in urban China. Urban Stud. 1999, 36, 1475-1494. [CrossRef]

40. Ho, S.P.S.; Lin, G.C.S. Emerging Land Markets in Rural and Urban China: Policies and Practices. China Q. 2003, 175, 681-707. [CrossRef]

41. Li, X.; Xu, X.X.; Li, Z.G. Land Property Rights and Urbanization in China. China Rev. 2010, 10, 11-37. [CrossRef]

42. Rosato-Stevens, M. Peasant land tenure security in china's transitional economy. Boston Univ. Int. Law J. 2008, 26, 97-141.

43. Statistical Bureau of Sichuan (SBS). Sichuan Statistical Yearbook 2014; China Statistics Press: Beijing, China, 2019.

44. Yang, S.Q.; Zhang, M.L.; Qian, L. The Way Out of Rural Vacant Houses under the Background of Urban-rural Integration. Rural Econ. 2015, 2015, 13-18. (In Chinese)

45. Voorhis, C.R.W.V.; Morgan, B.L. Understanding Power and Rules of Thumb for Determining Sample Sizes. Tutor. Quant. Methods Psychol. 2007. [CrossRef]

46. Green, S.B. How Many Subjects Does It Take To Do A Regression Analysis. Multivar. Behav. Res. 1991, 26, 499-510. [CrossRef]

47. Giudice, V.; Paola, P.; Forte, F. Using Genetic Algorithms for Real Estate Appraisals. Buildings 2017, 7, 31. [CrossRef]

48. Del Giudice, V.; De Paola, P.; Forte, F. Genetic Algorithms for Real Estate Market Analysis. In Proceedings of the Computational Science and Its Applications-ICCSA 2017, Trieste, Italy, 3-6 July 2017; Springer: Cham, Switzerland, 2017; pp. 467-477.

49. Shi, H.; Li, W. Fusing Neural Networks, Genetic Algorithms and Fuzzy Logic for Analysis of Real Estate Price. In Proceedings of the 2009 International Conference on Information Engineering and Computer Science, ICIECS, Wuhan, China, 19-20 December 2009. [CrossRef]

50. Gabrielli, L.; Bottero, M.; Oppio, A. Urban quality and real estate market: A hybrid approach based on Multicriteria Analysis and Hedonic Pricing model. Eur. Real Estate Soc. 2018. [CrossRef] 
51. Moreira, S.D.; Silva, S.R.; Fernandes, R.A.M. Real Estate Evaluation engineering suported by multicriteria analysis and artificial neural network. Sales. J. Inf. Syst. 2010, 6, 49-58.

52. Lunkevičius, S.; Ustinovičius, L.; Zavadskas, E.K. Possibilities of revitalization of unused rural property. Statyba 2001, 7, 44-55. [CrossRef]

53. Tay, L.; Kimhiang, L.; Joseph, O. Corporate Real Estate Performance: A Data-Driven Analysis. Available online: https://ideas.repec.org/p/arz/wpaper/eres2003_270.html (accessed on 25 October 2020).

54. Sharma, R. Segmentation and Space -Time Dynamics in the Real-Estate Market. Ph.D. Thesis, The University of Wisconsin, Milwaukee, Ann Arbor, MI, USA, 2009.

55. Tajani, F.; Morano, P.; Locurcio, M.; Torre, C. Data-driven techniques for mass appraisals. Applications to the residential market of the city of Bari (Italy). Int. J. Bus. Intell. Data Min. 2016, 11, 109-129. [CrossRef]

56. Yang, Y.J. Analysis of Housing Conditions, Willingness to Buy Houses and Influencing Factors of College Graduates in Wuhan. Master Thesis, Central China Normal University, Wuhan, China, 2019. (In Chinese).

57. Zhao, G.L.; Yang, G.Q. Analysis of the influencing factors of the willingness of farmer's homestead transfer-Based on the survey of farmer households in two counties and cities in Hubei. Resour. Environ. Yangtze River Basin 2009, 18, 1121-1124. (In Chinese)

58. Long, K.S.; Liu, C.Y.; Chen, L.G. Analysis on Peasants' Willingness-to accept and its Influencing Factors of Governance Patterns about Rural Idle Residential Land. China Popul. Resour. Environ. 2012, 22, 83-89. (In Chinese)

59. Peng, W.T.; López-Carr, D.; Wu, C.Z.; Wang, X.; Longcore, T. What factors influence the willingness of protected area communities to relocate? China's ecological relocation policy for Dashanbao Protected Area. Sci. Total Environ. 2020, 727, 138364. [CrossRef]

60. Cameron, A.; Trivedi, P. Microeconometrics Using Stata; Stata Press: Lakeway, TX, USA, 2010; Volume 5.

61. Statistical Bureau of Sichuan (SBS). Sichuan Statistical Yearbook 2018; China Statistics Press: Beijing, China, 2019.

62. Sharpe, D. Beyond Significance Testing: Reforming Data Analysis Methods in Behavioral Research. Can. Psychol. 2004, 45, 317-319. [CrossRef]

63. Hare, D. "Push" versus "pull" factors in migration outflows and returns: Determinants of migration status and spell duration among China's rural population. J. Dev. Stud. 1999, 35, 45-72. [CrossRef]

64. Song, M.J.; Wu, Y.L.; Chen, L. Does the land titling program promote rural housing land transfer in China? Evidence from household surveys in Hubei Province. Land Use Policy 2020, 97, 104701. [CrossRef]

65. Cloke, R.Y. Women's land rights and children' shuman capital in Vietnam. World Dev. 2013, 5, $18-31$.

66. Dijk, T.V. Scenarios of Central European land fragmentation. Land Use Policy 2003, 20, 149-158. [CrossRef]

67. Turner, L.M.; Hedman, L. Linking Integration and Housing Career: A Longitudinal Analysis of Immigrant Groups in Sweden. Hous. Stud. 2014, 29, 270-290. [CrossRef]

68. Tan, T.H. Use of Structural Equation Modeling to Predict the Intention to Purchase Green and Sustainable Homes in Malaysia. Asian Soc. Sci. 2013, 9, 181-191. [CrossRef]

Publisher's Note: MDPI stays neutral with regard to jurisdictional claims in published maps and institutional affiliations.

(C) 2020 by the authors. Licensee MDPI, Basel, Switzerland. This article is an open access article distributed under the terms and conditions of the Creative Commons Attribution (CC BY) license (http://creativecommons.org/licenses/by/4.0/). 